\title{
Official Development Assistance and Poverty Alleviation in Nigeria: An Error Correction Model Approach
}

\author{
Aderemi Timothy Ayomitunde, \\ Department of Economics, \\ Olabisi Onabanjo University, \\ Ago Iwoye, Ogun State, Nigeria.

\section{Sodeinde Gbemi Moses,} \\ Department of Business Entrepreneurship, \\ Kwara State University, Nigeria.
}

\author{
Yusuf Modupe Ololade, \\ Department of Economics, \\ Michael Otedaola College of Primary \\ Education, Lagos, Nigeria. \\ Aleshinloye Ibrahim Babatunde, \\ Department of Economics, \\ Michael Otedaola College of Primary \\ Education, Lagos, Nigeria.
}

(Received December 19, 2019; Accepted January 05, 2020)

\begin{abstract}
This study is examined the relationship between official development assistance and poverty alleviation in Nigeria which majority of studies in the past have failed to explore. Consequently, the study utilized an error correction model to address its objective. The major findings in this study are as follows. There is a significant negative relationship between official development assistance and household consumption per capita in Nigeria. This implies that official development assistance has no capacity to alleviate the current worrisome level of poverty in this country. However, FDI contributes to poverty alleviation in Nigeria though not significant. Furthermore, $11 \%$ of the error caused by shock was corrected annually in the model. The study therefore makes these recommendations for the policy makers; whenever alleviation of poverty is the target of the policy makers in the country, the Nigerian government should be committed to the provision of conducive investment environment that can facilitate further inflows of FDI from the developed countries, especially $G 7$ and $G 13$ countries. Also, the policy makers in Nigeria should not compromise in tailoring official development assistance towards projects and programs that have trickle down effects on the masses in Nigeria.
\end{abstract}

Keywords: ODA; Household Consumption Per Capita: Poverty Alleviation and ECM.

JEL: $C 82, B 41$

\section{INTRODUCTION:}

In the last thirty years, the countries in the Sub-Saharan Africa have received the estimated $40 \%$ of the global official development assistance followed by South and Central Asian countries which accounted for $20.7 \%$ (OECD, 2016). Similarly, from 1980 to1990, 1991 to 2000 and 2001 to 2015, the West African countries received $26 \%, 25 \%$ and $28 \%$ of the total African`s official development assistance concurrently (OECD, 2016). Meanwhile, it is instructive to state that Nigeria dominates the Economic Community of West African States sub region as regards the receipt of development assistance. The value of net official development assistance fluctuated between US\$118.1million in 1988 and US\$2.1billion in 2010. The figure rose sporadically to US\$6.4billion and US\$11.4billion in 2005 and 2006 concurrently. This is probably due to forgiveness of the country`s debt by the Paris Club of 
creditors. A cursory look at Official Development Assistance (ODA) data shows that wide fluctuations have remained a regular trend of ODA in Nigeria especially during the period 2010-2017.

However, one of the principal concerns in a bid to reinforce these core values of development namely: human sustenance; self-esteem and freedom is alleviation of poverty (Todaro and Smith, 2009: 2022). This justified the paramount reason why the first goal of the United Nation's Millennium Development Goals is centered on eradication of extreme poverty and hunger in the third world economies, with the mandate to reduce the proportion of people with income of less than $\$ 1$ per day and at same time the proportion of people suffering from hunger is reduced to half between 1990 and 2015, (Sachs, 2005:72). Yet, majority of developing countries are still lagging behind with high degree of poverty in which Nigeria is not insulated (United Nations, 2015).

Unfortunately, in 1970s, Nigeria`s the GDP per capita was among the 50 richest countries in the globe, but today, is the 'headquarters of poverty' (WDI, 2018). Nigeria is the sixth largest exporter of oil in the world nevertheless, nevertheless; one of the critical socio economic problems facing the country, currently, is high levels of poverty. The report by World Poverty Clock compiled by the Brookings institute, USA, as at May 2018 found that about 86.9 million Nigerians are in extreme poverty - the highest in the world (Adebayo, 2018). It is worth of note that this extreme level of poverty in the country has manifested in the various forms such as the inability of over $70 \%$ of the citizens to have access to basic necessities of life, over $60 \%$ live below a dollar per day, over 80 million youths unemployed, mass migration of young people to Europe through Sub Saharan desert, compromise of moral values or abandon moral values of the people and increasing rate of crimes among the populace on daily basis in the country.

However, ODA has been identified as a vital source of financing developmental project in developing economies. Also, aid has the capacity to propel development in a capital deficit country to its ultimate steady-state potential growth rate faster. And it can equally improve a country's steady state growth rate owing to its spillovers such as technical know-how and better governance that usually accompany the inflows of foreign capital.

Consequently, it is important to stress that one of the most critical challenges confronting developing countries today is the quest to eradicate poverty. The need to achieve the sustainable development goals (SDGs) in developing countries by 2030 has sparked off advocacy in some quarters for the usage of a holistic approach to tackle poverty in which ODA is one of the variables that could fast-track the process. As a result of this there should be a paradigm shift in research focus from economic growth to poverty reduction in the recent time because economic growth is not necessarily a sufficient condition for poverty reduction in developing countries. In Nigeria, an attempt to empirically verify the nexus between official development assistance and poverty alleviation has generated debates on appropriate policies. See N"edri Kan (2017), JideIbietan, Felix and Ese (2014), Okon, (2012), Akpan and Udoma (2011). Given the mixed findings and controversies identified in the literature, there is a need to re-establish the nature of the relationship that exists between ODA and poverty alleviation in Nigeria. Also, this study is unique because it employs error correction model that addresses the objective of this study in which past studies had undermined. The reason for the choice of this methodology was largely due to the one cointegration equation among the non-stationarity condition of all the variables of interest in this study. In meeting the research objective, this study examined the relationship between ODA and poverty alleviation between 1981 and 2017. Therefore, the timeline of 37 years is assumed to be sufficient enough for the employment of error correction model technique in this study.

The rest of this work is organized as follows; section two examines the review of relevant literature and section three presents methodology, discussion of results, conclusion and policy recommendation.

\section{THEORETICAL FRAMEWORK:}

It has been established in the literature by several aid experts and scholars that official development assistance was an offshoot of income transfer due to reparation payments after the Second World War II which led to the formation of the Marshall Plan (Ali and Zeb 2016; Kemp 1995). War brought the 
phenomenon of official development assistance into limelight with a view to ensuring fairness and betterment of people living in backward and underdeveloped countries (Ali and Zeb 2016).

Official development assistance became popular as a result of the continuous debate among the scholars and policy makers since the formation of the Marshall Plan, during the period of the late 1940s to the 1960s. The division of the globe into the first world, second world and third world has been argued to be the aftermath effect of the plan (Wood 2015; Black 1968).

Consequently, an attempt to advance various motives behind the inflows of the official development assistance in the world, Lloyd Black (1968) categorized the motives into four groups, namely defense, economic, political and humanitarian rationale. These periods were the early years in which Gross National Product (GNP) was the indicator of economic growth where the strategical indicators were the need for capital, investment and savings. Degnbol-Martinussen and Engberg-Pederse (2003) submitted that increasing GNP by aids recipient countries was synonymous to increasing the export of scarce resources needed by developed nations. Besides GNP, employment concept was also advocated to increase opportunities in recipient countries via the development of physical infrastructure. Meanwhile, Griffin (1991) concluded that the concept of diplomatic considerations as the major motivations behind the flow of official development a ssistance to former colonies by stressing the significance of support at the UN of donor countries maintaining their influence with these former colonies.

Therefore, it is apparent that the needs of developing countries played a major role in the formation of official development assistance, but the strategic interests of wealthy nations shaped the rationale for its operation.

\section{EMPIRICAL LITERATURE REVIEW:}

This section presents past empirical studies regarding official development and poverty.

However, JideIbietan, Felix and Ese (2014) submitted that despite the high flows of ODA in Nigeria on annual basis yet there is little or no impact on poverty alleviation in Nigeria. Askarov (2015) employed the technique of instrumental variables to establish that aid has a direct impact on economic growth in emerging economies. Similarly, Nedri Kan (2017) examined the nexus between official development assistance and poverty alleviation among ECOWAS countries with the application of panel data between 1980 and 2014. The results from the study indicated that the ODA contributed to poverty alleviation in the region. But, its impact on economic growth was inimical. As a result of this, the author submitted that ODA is pro-poor due to which no growth enhancement occurs in the ECOWAS sub region. In another perspective, Ali, Nishat and Anwar (2010) utilized the LIML point estimates to submit that a sustained inflow of 25 USD aid per capita is supposed to improve growth rate by around 50 percentage point on average At the same time, it also alleviates poverty by around 6.5 percentage points, gear up investment by around 1.5 percentage points in GDP, increase average schooling by 0.4 years and increase life expectancy by 1.3 years and bring about reduction in infant mortality by 7 in every 1000 births

Consequently, Eskander Alvi (2008) evaluated the relationship between aid and the importance of policy in generating economic growth with nonlinear relationship between the variables in developing countries. It was inferred from the study that policy constituted a pertinent factor that determines growth, and at the same time growth emanated from aid in a good policy environment, despite the fact there was an evidence to support diminishing returns to aid. While examining the effectiveness of aid on poverty reduction, Collier and Dollar (2002) used regression analysis to prove that the impact of aid on poverty is a function of its impact on per capita income growth. It was confirmed that the aid leads to economic growth, which eventually reduces poverty.

In the same vein, Akpan and Udoma (2011) investigated the impact of ODA on the performance of economy in Nigeria between 1970 and 2010 with the aid of least squares (3SLS) estimation technique. The study submitted that ODA has an insignificant effect on the Nigerian economic development. But capital expenditure brought about a significant economic development in the country.

Moreover, past studies on nexus between official development assistant and poverty alleviation in Nigeria are very scanty. This is also justifies the critical need to fill this gap in that regards. 
An Overview of Poverty Level and Official Development Assistance in Nigeria:

Figure 1: Household Consumption Per Capita in Nigeria

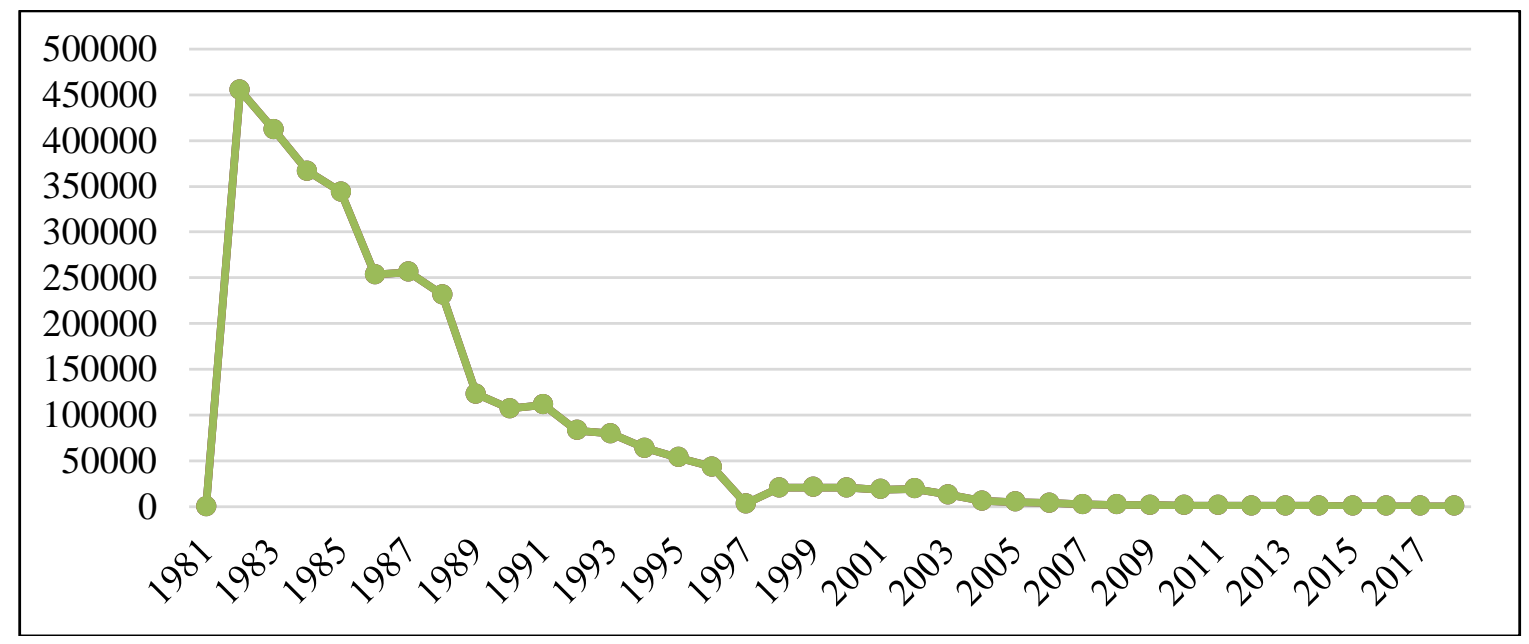

Source: (CBN, 2017)

Figure1 shows the household consumption per capita. This is used to measure the standard of living of individuals in Nigeria from 1981 to 2017. From the figure above, it is clear that living standard of individuals in Nigeria dwindles continuously from 1986. This shows that the level of poverty in Nigeria has been rising on annual basis from 1980s to 2017.

Figure 2: GDP Per Capita Growth in Nigeria

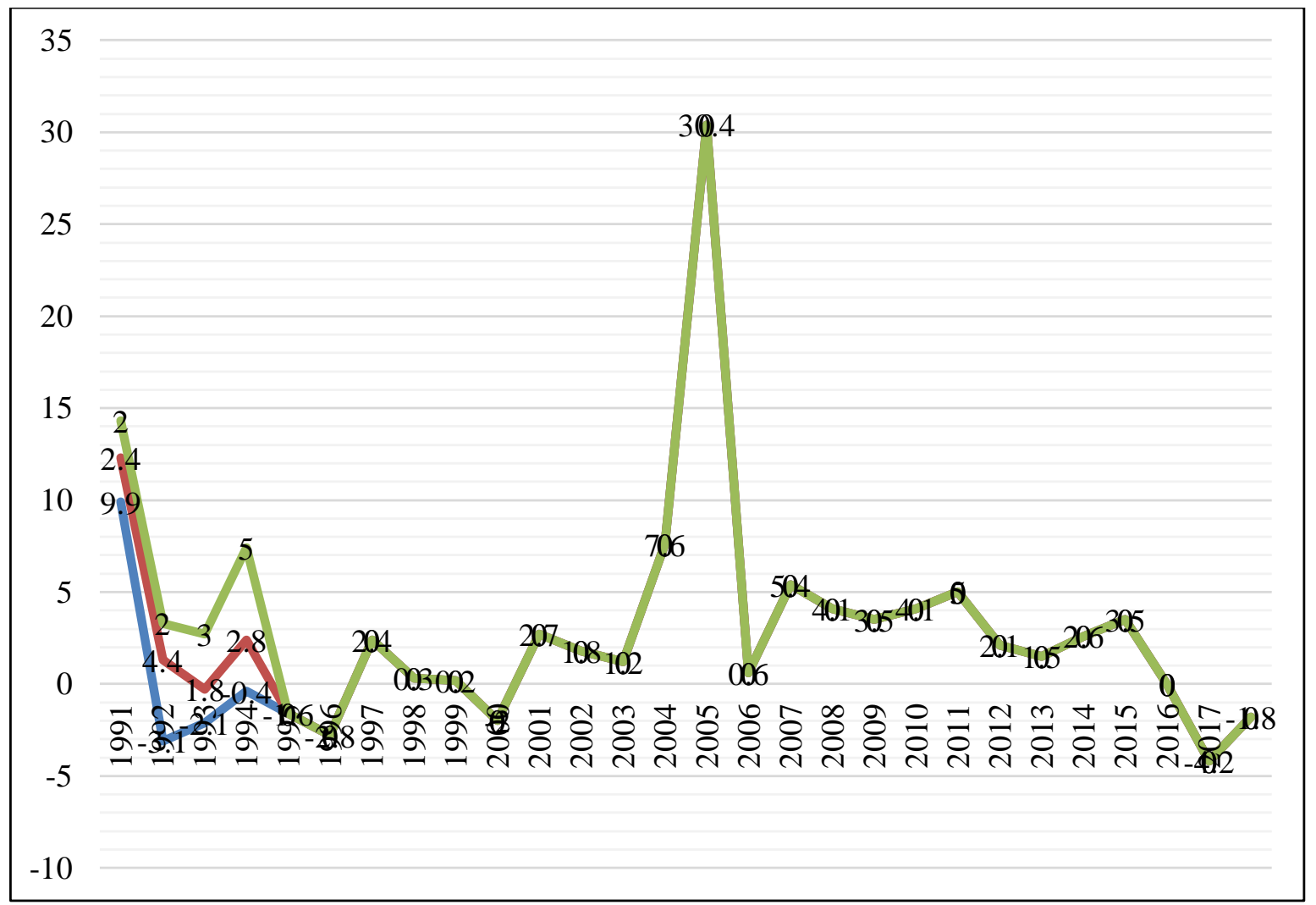

Source: (WDI, 2018)

As shown in Figure 1, the GDP per capita growth which measures the standard of living in an economy has been not been impressive in the country. It could be pinpointed from the figure above that in the last twenty 
seven years (1990-2017), this variable has been fluctuating. It is instructive to state that the impressive performance of this variable in 2004 and 2005 especially could be attributed to forgiveness of the country`s debt by the Paris Club of creditors in year 2005. Consequently, between 2006 and 2014 this variable has been fluctuating as well until it came to a standstill in 2015 and thereafter recorded negative growth in 2016 and 2017 concurrently, which serves as evidence of spillovers of recession in Nigerian economy. The implication of this is that on the aggregate, poverty has been growing consistently in Nigeria which is reflected in the continuous dwindling of welfare of the people in the country.

Figure 3: Relationship between Official Development Assistance and Household Consumption per Capita

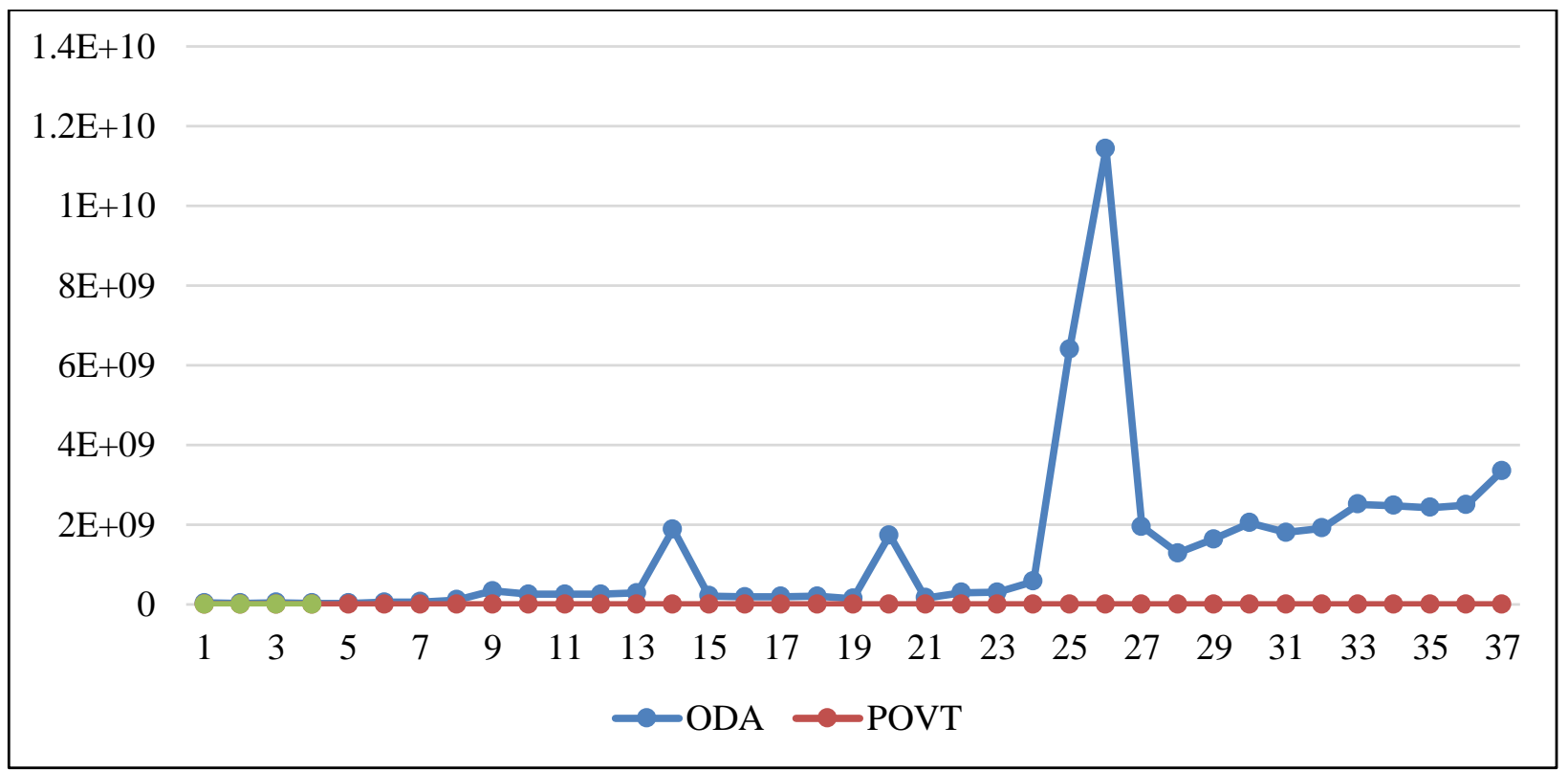

Source: (WDI, 2018)

Figure 3 shows the interaction between official development assistance and household consumption per capita. It could be observed from the figure that in pre sap era there was no significant difference between the inflows of ODA and household consumption per capita in the country. However, from 2005, ODA began to rise above household consumption per capita significantly due to debt forgiveness by the Paris Club in year 2005. Since then there has been a wide gap between the variables in the country especially during the periods of 2005 and 2006

\section{METHODOLOGY:}

This study utilized secondary data from 1981 to 2017. Data on official development assistance was extracted from World Development Indicator, meanwhile data on foreign direct investment were sourced from (UNCTAD, 2018) investment report and data on household consumption per capita (poverty level) were sourced from the Central Bank of Nigeria Statistical Bulletin.

\section{Model Specification:}

In addressing the objective of this study, the model could be specified as follows

$\mathrm{PVT}=\mathrm{F}$ (ODA, FDI, EXR).

While linearizing model (I), it gives birth to model (II)

LnPVTt $=\beta_{1}+\beta_{2}$ LnODAt $+\beta_{3}$ LnFDIt $+\beta_{4} \operatorname{LnEXR}+\mu_{\mathrm{i}}$

Where;

PVT $=$ Poverty level, ODA represents official development ssistance. FDI = Foreign Direct Investment, $\mathrm{EXR}=$ Exchange Rate, $\beta 1=$ Intercept, $\beta 2-\beta 4=$ coefficients of independent variables, $\mu \mathrm{i}=$ Stochastic or error term and $\mathrm{t}=1981-2017$.

It is expected that $\beta 2$ and $\beta 3>0, \beta_{4}<0$. 
In order to estimate the long run relationship alongside with the short run relationship between the variables, the short run error correction model is specified explicitly as follows.

$\Delta \mathrm{PVT}_{\mathrm{t}}=\beta_{0}+\sum_{\mathrm{i}=1}^{\mathrm{p}} \beta_{1} \Delta \mathrm{PVT}_{\mathrm{t}-1}+\sum_{\mathrm{i}=0}^{\mathrm{p}} \beta_{2} \Delta \mathrm{ODA}_{\mathrm{t}-1}+\sum_{\mathrm{i}=0}^{\mathrm{p}} \beta_{3} \Delta \mathrm{FDI}_{\mathrm{t}-1}+\sum_{\mathrm{i}=0}^{\mathrm{p}} \beta_{4} \Delta \mathrm{EXR}_{\mathrm{t}-1}+$ $\varnothing \mathrm{ECM}_{\mathrm{t}-1}+\sum_{\mathrm{i}=1}^{\mathrm{p}} \beta_{1} \mathrm{PVT}_{\mathrm{t}-1}+\sum_{\mathrm{i}=0}^{\mathrm{p}} \beta_{2} \mathrm{ODA}_{\mathrm{t}-1}+\sum_{\mathrm{i}=0}^{\mathrm{p}} \beta_{3}$ FDI $_{\mathrm{t}-1}+\sum_{\mathrm{i}=0}^{\mathrm{p}} \beta_{4} \mathrm{EXR}_{\mathrm{t}-1}+\mathrm{U}_{\mathrm{t}^{---}}$(iv)

The $\mathrm{ECM}_{\mathrm{t}-1}$ is the error correction term of the short run equation.

\section{Measurement of Variables:}

For the purpose of achieving the stated objectives in this study, the operational definitions of the variables employed can be captured as follows

FDI: This measures the total foreign direct investment in all sectors of the Nigerian economy.

Poverty Level: This is measured by household consumption per capita in Nigeria.

ODA: Official development assistance is measured by foreign development aid in terms of disbursements of loans made on concessional terms (net of repayments of principal) and grants by official agencies to Nigeria.

\section{RESULTS AND DISCUSSION:}

Table 1: Descriptive Statistics of Annual Data Series (1981-2017)

\begin{tabular}{|l|c|c|c|c|}
\hline \multicolumn{1}{|c|}{ Descriptive Statistics } & FDI & ODA & PVT & EXR \\
\hline Mean & $2.72 \mathrm{E}+09$ & $1.34 \mathrm{E}+09$ & 84360.76 & 3.784564 \\
\hline Median & $1.88 \mathrm{E}+09$ & $3.00 \mathrm{E}+08$ & 19183.74 & 4.543831 \\
\hline Maximum & $8.92 \mathrm{E}+09$ & $1.14 \mathrm{E}+10$ & 455049.4 & 5.886104 \\
\hline Minimum & 2228246 & 31710000 & 358.3200 & -0.298855 \\
\hline Std. Deviation & $2.68 \mathrm{E}+09$ & $2.16 \mathrm{E}+09$ & 130410.1 & 1.390775 \\
\hline Skewness & 0.923716 & 0.171001 & 0.628987 & -1.257628 \\
\hline Kurtosis & 2.724292 & 4.495041 & 4.370940 & 3.703400 \\
\hline Jargue-Bera & 5.378907 & 265.7169 & 19.26137 & 10.51614 \\
\hline Probability & 0.067918 & 0.000000 & 0.000066 & 0.005205 \\
\hline Sum & $1.00 \mathrm{E}+11$ & $4.96 \mathrm{E}+10$ & 3121348 & 140.0289 \\
\hline Sum. Sq. Deviation & $2.59 \mathrm{E}+20$ & $1.68 \mathrm{E}+20$ & $6.12 \mathrm{E}+11$ & 69.63318 \\
\hline Observation & 37 & 37 & 37 & 37 \\
\hline
\end{tabular}

Table 1 shows the descriptive statistics of the data employed for econometric analysis in this study. To ensure that the assumptions of normality and asymptotic properties of data series are satisfied, this paper has examined various descriptive statistics such as the mean, median, minimum and maximum values; and the distribution of the sample measured by the skewness, kurtosis and Jaque-Bera statistics. The values of the mean and the media of variables like ODA, exchange rate and FDI are not too wide from each other. However, the reverse is the case of the variable used to proxy poverty level. This implies that the distribution of the data series is a little bit symmetrical. This is also reflected in the value of Kurtosis which is not far from 3. 
Table 2: Unit Root Test

\begin{tabular}{|c|c|c|c|c|c|}
\hline \multirow{2}{*}{ Variables } & \multicolumn{5}{|c|}{ ADF Test } \\
\hline & Level & P Value & $1^{\text {st }}$ Diff & P Value & Remark \\
\hline LODA & $-2.95842 * *$ & 0.3215 & $-2.98404 * *$ & 0.0000 & I (1) \\
\hline LFDI & $-2.95842 * *$ & 0.5318 & $-2.98404 * *$ & 0.0009 & I (1) \\
\hline LPVT & $-2.98404 * *$ & 0.8833 & $-2.98404 * *$ & 0.0000 & I (1) \\
\hline EXR & -2.945842 & 0.5846 & -2.948404 & 0.0000 & I (1) \\
\hline \multirow{2}{*}{ Variables } & \multicolumn{5}{|c|}{ PP Test } \\
\hline & Level & P Value & $1^{\text {st }}$ Diff. & P Value & Remark \\
\hline LODA & $-2.94552 * *$ & 0.4703 & $-2.948504 * *$ & 0.0000 & I (1) \\
\hline LFDI & $-2.945852 * *$ & 0.5732 & $-2.948504 * *$ & 0.0005 & I (1) \\
\hline LPVT & $-2.945542 * *$ & 0.9061 & $-2.948504 * *$ & 0.0000 & I (1) \\
\hline EXR & -2.945842 & 0.5564 & -2.948404 & 0.0000 & I (1) \\
\hline
\end{tabular}

**\% \% level

Time series data is usually associated with the problem of unit root which could cause spurious results if such problem is not resolved in the study. Meanwhile, the validity of the policy recommendation based on such data with a unit root is questionable. Therefore, this paper subjected to a unit root test through the technique of the standard Augmented (Dickey-Fuller (ADF) 1981; Phillips-Perron (PP) 1988) tests. Consequently, the estimated results from the table show that data for all the variables were stationary after first differencing. This implies that the data employed for this analysis possess a unit root.

Table 3: Johansen Cointegration Test (Trace Statistics) and (Maximum Eigenvalue)

\begin{tabular}{|c|c|c|c|c|c|}
\hline Null Hypothesis & Eigenvalue & Trace Statistics & P-value & Maximum Eigenvalue & P-value \\
\hline $\mathrm{r}=0$ & 0.552360 & 54.21347 & 0.1114 & 28.13182 & 0.3191 \\
\hline $\mathrm{r} \leq 1$ & 0.471836 & 26.08165 & 0.2176 & 22.34217 & 0.1607 \\
\hline $\mathrm{r} \leq 2$ & 0.101333 & 3.739478 & 0.0531 & 3.739478 & 0.0551 \\
\hline
\end{tabular}

Source: Authors`Computation (2019); Johansen \& Juselius (1990)

The results of the pre-estimation unit root tests established that the variables of interest in this study possess a unit root. The implication of this is that these variables might show deviation in the short run, yet there is high possibility they have a long run equilibrium relationship. In order to examine the existence or otherwise of the long run convergence of the variables, the study utilized cointegration test. Consequently, the results of this test indicate the existence of at most one cointegrating vectors in the systems from the eigenvalue and the maximal eigenvalue statistics. Hence, the variables of interest in this paper have a long run equilibrium relationship with one another, though they might likely show some adjustment to short run disequilibrium. Hence, the error correction model was estimated to capture the long run relationship alongside with the short run disequilibrium in the model. 
Table 4: VAR Lag Order Selection Criteria

Endogenous variables: POVT

Exogenous variables: C ODA FDI EXR

Sample: 19812017

Included observations: 34

\begin{tabular}{|c|c|c|c|c|c|c|}
\hline Lag & LogL & LR & FPE & AIC & SC & HQ \\
\hline 0 & -427.3483 & NA & $5.78 \mathrm{e}+09$ & 25.31461 & 25.44929 & 25.36054 \\
\hline 1 & -382.6944 & 78.80116 & $4.43 \mathrm{e}+08$ & 22.74673 & 22.92630 & 22.80797 \\
\hline 2 & -381.0108 & 2.871904 & $4.26 \mathrm{e}+08$ & 22.70652 & 22.93098 & 22.78307 \\
\hline 3 & -377.6072 & $5.606031^{*}$ & $3.71 \mathrm{e}+08^{*}$ & $22.56513 *$ & $22.83449 *$ & $22.65699 *$ \\
\hline
\end{tabular}

* indicates lag order selected by the criterion

Model was subjected to the conventional diagnostic tests such as Final prediction error, Schwarz information criterion, Schwarz information criterion, the Akaike Information Criterion and Hannan-Quinn information criterion for the appropriate lag length selection was adopted in choosing the appropriate lag length. The results in the above table show that lag 3 is used in estimating relationship between the variables of interest within the ECM framework

Table 5: Parsimonious Error Correction and Long Run Regression Estimates for ODA and Poverty Alleviation in Nigeria

Dependent Variable: DPOVT

\begin{tabular}{|c|c|c|c|c|c|c|c|}
\hline Variable & Coefficient & $\begin{array}{c}\text { t- } \\
\text { statistics }\end{array}$ & $\begin{array}{c}\text { P- } \\
\text { value }\end{array}$ & Variable & Coefficient & $\begin{array}{c}\text { t- } \\
\text { statistics }\end{array}$ & $\begin{array}{c}\text { P- } \\
\text { value }\end{array}$ \\
\hline D (POVT(-3) & $0.514201 * *$ & 3.3 & 0.0033 & POVT(-3) & -0.007343 & 0.04 & 0.9634 \\
\hline D (FDI(-3) & 1.292206 & 0.3 & 0.7439 & FDI(-3) & $8.71 \mathrm{E}-07$ & 0.2 & 0.8137 \\
\hline D (ODA(-3) & $-6.22008 * *$ & 3.1 & 0.0454 & ODA(-3) & $-4.49 \mathrm{E}-07 * *$ & 2.4 & 0.0594 \\
\hline D (EXR(-3) & 0.161101 & 0.4 & 0.6247 & (EXR(-3) & $-0.755068^{* *}$ & 2.5 & 0.0186 \\
\hline ECM (-1) & $-0.10851 * *$ & 2.9 & 0.0377 & & & & \\
\hline R-Squared & 0.735712 & & & & & & \\
\hline Adjusted R-Squared & 0.584690 & & & & & & \\
\hline Durbin-Watson stat & 2.144217 & & & & & \\
\hline
\end{tabular}

Source: Authors`Computation (2019) ***Significant at 10\%, **Significant at 5\%, *Significant at 1\%,

Table 5 shows the results of the estimated error correction model. The error correction term, ECM (-1) has an expected sign and significant at the same time. This shows that about $11 \%$ error orchestrated by external shock in the model is corrected annually. In other words, the model corrects its short run disequilibrium by about 11 percent speed of adjustment in order to return to the long run equilibrium. This implies that all the variables of interest in the model converged in the long run. In the same vein, the third differenced lagged value of the dependent variable- D(POVT(-3) is negative but insignificant 
in the long run. This implies that the poverty level in the previous year increases the level of poverty in the current year in the long run. However, the coefficient of official development assistance at lag 3 shows that this variable has a negative and significant relationship with household consumption per capita in Nigeria both in the short run and long run. A unit change in official development assistance reduces household consumption per capita by $6.2 \%$ and $4.5 \%$ in Nigeria in the short run and long run respectively. The implication of this finding is that official development assistance could not alleviate poverty in Nigeria. The reason for this negative result might be the high level of embezzlement of public funds by public office holders and investment in white elephant projects in the country. This finding is in line with the conclusion of JideIbietan, Felix and Ese (2014) who opined that despite the high flows of ODA in Nigeria, there is little or no impact on poverty alleviation in the country. But, it contradicts the submission of $\mathrm{N}^{\text {ed }}$ dri Kan (2017) in a related study in ECOWAS countries. Exchange rate and household consumption per capita have a significant relationship in the long run. However, the relationship between FDI and household consumption per capita is positive but insignificant at the all lags. As FDI inflows changes by a unit, the household per capita increases by $1.3 \%$ and $8.7 \%$ in the short run and long run simultaneously at lag 3. This implies that FDI inflows contributes to poverty alleviation though not significant in Nigeria. This submission is validated by the findings of Israel (2014). Further, it contradicts the submission of Ogunniyi and Igberi (2014), Akinmulegun (2012) and Ali, Nishat and Anwar (2010) in similar studies in Nigeria and Pakistan respectively.

\section{Diagnostic and Stability Tests:}

Table 6: Diagnostic Tests
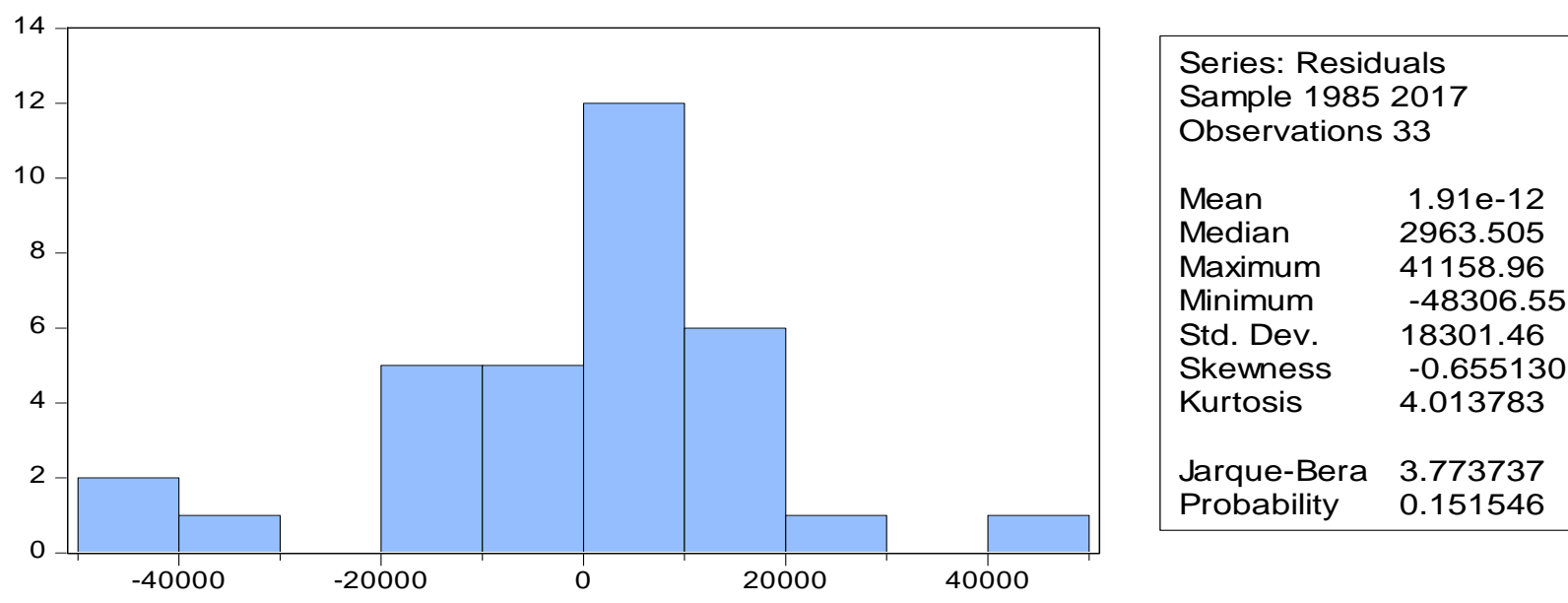

Heteroskedasticity Test: Breusch-Pagan-Godfrey

\begin{tabular}{|l|c|l|c|}
\hline F-statistic & 4.885248 & Prob. F(10,22) & 0.0009 \\
\hline Obs*R-squared & 22.75336 & Prob. Chi-Square(10) & 0.0117 \\
\hline Scaled explained SS & 15.23860 & Prob. Chi-Square(10) & 0.1236 \\
\hline
\end{tabular}

\section{Breusch-Godfrey Serial Correlation LM Test:}

\begin{tabular}{|l|l|l|c|}
\hline F-statistic & 2.370430 & Prob. F(2,20) & 0.1192 \\
\hline Obs*R-squared & 6.323482 & Prob. Chi-Square(2) & 0.0424 \\
\hline
\end{tabular}


Figure 4: Stability Tests

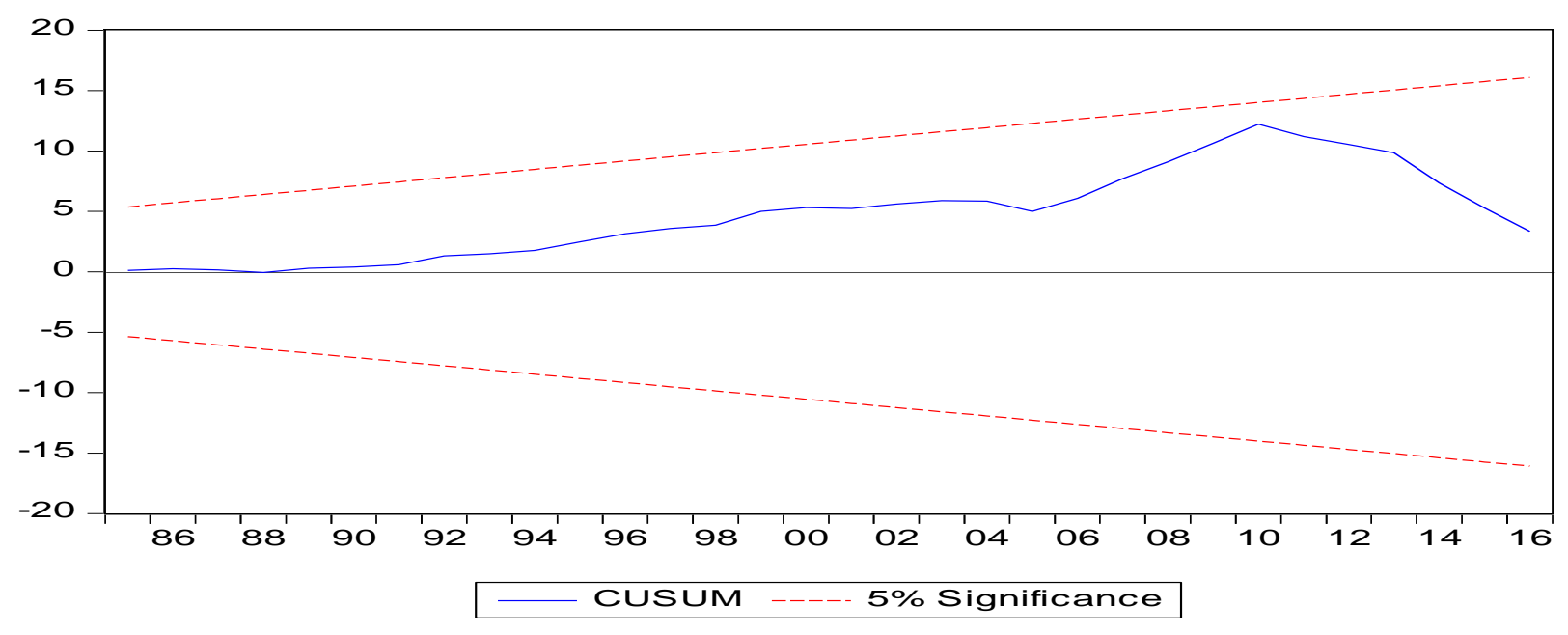

The appropriateness of the parsimonious model was further verified by carrying out various diagnostic tests and stability tests such as the Serial Correlation LM test, Heteroskedasticity and the histogram and normality test) and Cumulative Sum (CUSUM) on the residual. Consequently, the results presented in the above table shows that the F-statistics of the Serial Correlation LM test and Heteroskedasticity test of the model is not significant; this proved that there is no serial correlation and heteroskedasticity in the residuals of the estimated model. Also, cumulative sum (CUSUM) test confirms the stability of the estimated parameters over the period 1981-2017, because it lies within critical bounds of 5\% significant level. Hence, the model has been reasonably specified.

\section{CONCLUSION AND RECOMMENDATIONS:}

An investigation about the relationship between official development assistance and poverty alleviation in Nigeria over the period of 1981 to 2017 has been carried out in this study. The test for cointegration proved that there is a long-run equilibrium relationship among official development assistance, FDI and poverty level in Nigeria, while the error correction term indicated that about $11 \%$ of the total disequilibrium corrected on the annual basis in the model. However, there is a significant inverse relationship found between official development assistance and household consumption per capita as a proxy for poverty level in Nigeria. This implies that official development assistance has no capacity to alleviate the current worrisome level of poverty in this country. Meanwhile, the contribution of FDI has led to poverty alleviation in Nigeria, but not significantly. The reason for this insignificant spillover might be connected to the larger percentage of FDI inflows which goes to oil and gas in Nigeria which may not translate to the welfare of the average Nigerian over the time. Furthermore, the paramount findings that emanated from this paper brought about the following recommendations for both policy makers and the general public that official development assistance is not capable of alleviating poverty in Nigeria. But FDI inflows have the potential to alleviate poverty levels in Nigeria if channeled towards projects that have trickled down effects on the masses. As such, policy makers in Nigeria should be more committed to provide a better investment climate so as to facilitate further inflows of FDI from developed countries. Also, policy makers should earmark official development assistance towards projects and programs that have trickle down effects on the masses in Nigeria.

\section{REFERENCES:}

Adebayo, B. (2018). Nigeria overtakes India in extreme poverty ranking [Online]. https://edition.cnn.com/ 2018/06/26/africa/nigeria-overtakesindiaextreme-poverty-intl/index.html 21.12.2018.

Akinmulegun, S.O. (2012). Foreign direct investment and standard of living in Nigeria, Journal of Applied Finance and Banking, Vol. 2, No. 3, PP. 21-32. 
Akpan H. E. \& Udoma, J. A. (2011). Official Development Assistance and Economic Performance in Nigeria, 1970-2010, Journal of Monetary and Economic Integration. Vol. 12, No. 1, PP. 125-150

Ali, M., \& Zeb, M. (2016). Foreign Aid: Origin, Evolution and its Effectiveness in Poverty Alleviation. The Dialogue, 11.1

Ali, M., Nishat, M. \& Anwar, T. (2010). Do foreign inflows benefit Pakistan poor? The Pakistan Development Review, Vol. 48, No. 4, PP.43-57

Askarov (2015). Development Aid and Growth in Transition Countries, World Development, Vol. 66, PP. 383-399.

Black, L. D. (1968). Chapter 2: The Rationale - Why Foreign Aid? In Black, Lloyd D., The Strategy of Foreign Aid, pp. 13-21, Princeton: D. Van Nostrand

CBN (2017). Statistical Bulletin, Central Bank of Nigeria

Collier, P. \& Dollar, D. (2002). Aid allocation and poverty reduction, European Economic Review 46 (8): $1475-1500$

Degnbol-Martinussen and Engberg-Pedersen, (2003). Aid: Understanding International Development Cooperation, London: Zed Books.

Dickey, D. A. \& Fuller, W. A. (1981). Likelihood Ratio Tests for Autoregressive Time Series with a Unit Root, Econometrica, Vol. 49, P.P. 1057 - 1072.

Eskander Alvi, D. (2008). Aid, Policies, and Growth in Developing Countries A New Look at the Empirics, Southern Economic Journal, Vol. 74, No. 3, PP. 693-706

Griffin, K. (1991). Foreign Aid after the Cold War, Development and Change, Vol. 22, No. 4, PP. 645-85. DOI: https://doi.org/10.1111/j.1467-7660.1991.tb00430.x

Israel A.O. (2014). Impact of foreign direct investment on poverty reduction in Nigeria, Journal of Economics and Sustainable Development, Vol. 20, No.5 PP 23-35.

Jide, I., Felix C. \& Ese U. (2014). Poverty Alleviation and the Efficacy of Development Assistance Models in Nigeria: An Appraisal, International Journal of Humanities Social Sciences and Education (IJHSSE), Vol. 1, No. 5, PP. 1-8.

Johansen, S. \& K. Juselius (1990). Maximum Likelihood Estimation and Inference on Cointegration with Applications to Demand for Money, Oxford Bulletin of Economics and Statistics, 52, PP. 169-210.

Kemp, M. (1995). The static welfare economics of foreign aid, in the gains from Trade and the gain from Aid: Essays in International Trade Theory. Routledge, NY

Needri Kan David (2017). Contribution of Official Development Assistance to Poverty Alleviation in the Ecowas, IOSR Journal of Economics and Finance (IOSR-JEF), Vol. 8, No. 2, PP. 37-49

OECD (2016). www.oecd.org/development/financing-sustainable-development/final-ODA.htm

Ogunniyi M.B. \& Igberi C.O. (2014). The Impact of Foreign Direct Investment on Poverty Reduction in Nigeria, Journal of Economics and Sustainable Development, Vol. 5, No.14, PP.12-25

Okon, E. (2012). Five Decades of Development Aid to Nigeria: The Impact on Human Development, Journal of Economics and Sustainable Development, Vol. 3, No.1, PP. 32-42.

Phillips, P. C. \& Perron, P. (1988). Testing for a unit root in time series regression, Biometrika, Vol. 75, PP.335-346

Sachs, J. (2005). The End of Poverty. Penguin Books: London

Todaro, M.P. \& Smith, S.C. (2009). Economic Development. England: Pearson Education Limited

UNCTAD (2018). World investment Report 2018 published by the United Nations on Trade and Investment available at unctad.org/DATA\%20on\%20FDI\%20BRICS\%201.htm.

United Nations (2015). Millennium Development Goals Report, United Nations.

Wood, T. (2015). Who supports Australian aid? - Devpolicy Blog from the Development Policy Centre. Retrieved on January 28, 2016 from http://devpolicy.org/who-supports-australian-aid-20151118/

World Bank (2018). World Development Indicators. Washington D.C 